\title{
Studi Kelayakan LKS Praktikum Berbasis Pendekatan Saintifik Serta Dampaknya pada Hasil Belajar Materi Sifat Larutan Penyangga
}

\author{
Deysi Demo $^{* a}$, Freetje Waworuntu $^{a}$, Abdon Saiya ${ }^{a}$ \\ ${ }^{a}$ Kimia, FMIPA, Universitas Negeri Manado, Minahasa, 95618, Indonesia
}

\begin{tabular}{l} 
I N F O A R T I K E L \\
\hline Diterima 11 November 2019 \\
Disetujui 31 Desember 2019 \\
\hline Key word: \\
Feasibility of practicum \\
student worksheet \\
Nature of buffer solution \\
Scientific approach \\
\\
\hline Kata kunci: \\
Kelayakan LKS praktikum \\
Sifat larutan penyangga \\
Pendekatan saintifik
\end{tabular}

${ }^{*} e$-mail:

nataliademodeysi@gmail.com *Telp: 081342218706

\begin{abstract}
A B S T R A C T
This research aims to determine the product feasibility of practicum student worksheet based on scientific approach and determine its impact on learning outcomes, especially the nature of the buffer solution by seeing how many students reach or exceed the minimum completeness criteria (KKM). Type of this research is research and development carried out in class XI science 5 SMAN 1 Tondano.. Based on the recapitulation results, student worksheet was stated valid with a value of $83.8 \%$. Seen from student response in small group trials and large group trials, student worksheet was stated practical with succesive values of $88.17 \%$ and $92.98 \%$. Its impact on student learning outcomes is that most students in small group trials and students in large group trials have exceeded the specified KKM with completeness scores obtained of $66.67 \%$ and $89.47 \%$ respectively. Hypothesis test for learning outcomes use the left side $t$-test obtained $t_{\text {count }}(8,517)>t_{\text {table }}(1,734)$ which means accept $H_{0}$ or reject $H_{1}$. Based on the results obtained it can be concluded that the practicum student worksheet based on the scientific approach developed is feasible to be used in the learning process.
\end{abstract}

\section{ABSTRAK}

Penelitian ini bertujuan untuk mengetahui kelayakan produk LKS praktikum berbasis pendekatan saintifik dan mengetahui dampaknya pada hasil belajar khususnya materi sifat larutan penyangga dengan melihat seberapa banyak siswa yang mencapai atau melampaui KKM. Jenis penelitian ini adalah penelitian dan pengembangan yang dilakukan di kelas XI IPA 5 SMAN 1 Tondano. Berdasarkan hasil rekapitulasi, LKS praktikum berbasis pendekatan saintifik dinyatakan valid dengan nilai sebesar 83,8\%. Dilihat dari respon siswa pada uji coba kelompok kecil dan kelompok besar LKS dinyatakan praktis dengan nilai berturut-turut sebesar $88,17 \%$ dan $92,98 \%$. Dampak penggunaan LKS terhadap hasil belajar siswa adalah sebagian besar siswa pada uji coba kelompok kecil dan siswa pada uji coba kelompok besar telah melampaui KKM yang sudah ditetapkan dengan nilai ketuntasan yang diperoleh berturut-turut sebesar $66,67 \%$ dan $89,47 \%$. Pengujian hipotesis untuk hasil belajar menggunakan uji $t$ pihak kiri diperoleh nilai thitung $(8,517)>\operatorname{tabel}(1,734)$ yang berarti terima $\mathrm{H}_{0}$ atau tolak $\mathrm{H}_{1}$. Berdasarkan hasil yang diperoleh dapat disimpulkan bahwa LKS praktikum berbasis pendekatan saintifik yang dikembangkan layak digunakan dalam proses pembelajaran.

\section{Pendahuluan}

Kehidupan manusia sangat berkaitan dengan kimia, hampir setiap perubahan materi melibatkan proses kimia seperti proses pernapasan, pencernaan makanan, perkaratan besi, dll. Oleh karena itu, sangatlah penting bagi kita untuk mempelajari kimia. Ilmu kimia tidak hanya mempelajari penguasaan sekumpulan pengetahuan seperti konsep, fakta ataupun prinsip tetapi juga mengetahui proses penemuan, penguasaan petunjuk ataupun metode ilmiah [1].

Namun pada kenyataannya mata pelajaran kimia dianggap sulit, menakutkan serta membosankan oleh sebagian siswa. Hal ini disebabkan karena konsep-konsep kimia yang 
kompleks serta sebagian besar bersifat abstrak [2].

Permasalahan tersebut dapat diatasi dengan metode praktikum di mana dengan diadakannya praktikum membuat peserta didik lebih yakin atas sesuatu hal, mampu menemukan fakta dengan inderanya sendiri, dapat memperkaya pengalaman belajar, pengembangan sikap ilmiah serta hasil belajar lebih tersimpan lama dalam ingatan peserta didik [3]. Namun praktikum pada umumnya belum memberikan kesempatan kepada peserta didik untuk berpartisipasi secara aktif sehingga mereka kurang memahami apa yang dipraktekkan dan alasannya melakukan praktikum tersebut.

Dari hasil wawancara dengan guru kimia di SMAN 1 Tondano, diketahui bahwa siswa masih merasa kesulitan dalam memahami konsep materi kimia yang bersifat abstrak yang mengakibatkan hasil belajar peserta didik banyak yang berada di bawah kriteria kentuntasan minimal (KKM). Selain itu, kegiatan praktikum di SMAN 1 Tondano belum dilakukan secara rutin. salah satu kendalanya adalah lembar kerja siswa (LKS) yang lebih mendukung dalam mengatasi masalah pemahaman konsep peserta didik belum tersedia. Praktikum yang biasa dilakukan diambil dari buku paket siswa, bersifat petunjuk langsung sehingga siswa hanya melakukan kegiatan praktikum sesuai petunjuk dalam buku paket tersebut tanpa mencari tahu alasan mengapa pengerjaannya dilakukan secara bertahap. LKS berperan besar dalam proses pembelajaran di mana fungsi LKS adalah sebagai acuan untuk memandu kegiatan pembelajaran serta dapat juga digunakan sebagai alat untuk menilai proses pembelajaran yang berlangsung [4].

Informasi lain yang didapatkan dari wawancara adalah belum dikembangkannya LKS yang memuat pendekatan-pendekatan pembelajaran yang mudah dipahami oleh peserta didik seperti pendekatan saintifik. LKS yang memuat pendekatan saintifik dapat dirumuskan dengan jelas dan sederhana, serta sistem penyajiannya menarik. Dimana aktivitas di dalamnya adalah menalar, menemukan, berisi pengabsahan serta penjelasan tentang suatu fakta atau kebenaran [5].
Berdasarkan uraian di atas, maka peneliti dalam penelitian ini akan mengembangkan dan menguji kelayakan produk LKS praktikum khususnya pada materi sifat larutan penyangga dengan menggunakan pendekatan saintifik agar siswa lebih berpartisipasi secara aktif untuk mencari dan menyelidiki secara terarah, kritis serta logis sehingga siswa dapat memahami konsep yang dipelajari dan berujung pada peningkatan hasil belajar siswa.

Tujuan dari penelitian ini untuk mengetahui kelayakan LKS praktikum berbasis pendekatan saintifik dan dampaknya terhadap hasil belajar pada materi sifat larutan penyangga.

\section{Metode}

Jenis penelitian ini adalah penelitian dan pengembangan atau research and development menurut Borg and Gall. Dalam penelitian ini sesuai dengan namanya informasi dan datadata yang dibutuhkan peneliti didapatkan dengan research sedangkan development dilakukan untuk menghasilkan atau mengembangkan suatu produk seperti perangkat pembelajaran. Pada penelitian ini tahap pengembangan hanya dilakukan sampai langkah ke tujuh dari 10 langkah, yaitu: 1) penelitian dan pengumpulan data, 2) perencanaan, 3) pengembangan produk, 4) uji coba lapangan awal, 5) revisi hasil uji coba lapangan awal, 6) uji coba lapangan utama, 7) penyempurnaan produk hasil uji coba lapangan utama [1].

Subjek dalam penelitian ini merupakan siswa kelas XI IPA 5 SMAN 1 Tondano tahun pelajaran 2018/2019. Pengambilan sampel dilakukan dengan menggunakan teknik simple random sampling di mana penentuan sampel dari semua anggota populasi dilakukan secara acak. Sampel dalam penelitian ini dibagi menjadi dua kelompok yaitu kelompok kecil untuk uji coba lapangan awal yang berjumlah 6 siswa dan kelompok besar untuk uji coba lapangan utama berjumlah 19 siswa.

Teknik pengumpulan data dalam penelitian ini meliputi teknik wawancara, teknik komunikasi tidak langsung, serta teknik pengukuran (tes pencapaian hasil belajar). instrumen penelitian yang digunakan adalah lembar validasi, angket respon siswa, soal 
posttest.

\section{Analisis dan Interpretasi Data}

Metode analisis data yang digunakan dalam penelitian adalah mixed methods yang terdiri dari:

1. Analisis Hasil Uji Coba Instrumen Tes

a. Validitas

Untuk menguji kevalidan instrumen tes digunakan rumus korelasi product moment.

$$
r_{x y}=\frac{N \sum X Y-\left(\sum X\right)\left(\sum Y\right)}{\sqrt{\left(N \sum X^{2}-\left(\sum X\right)^{2}\right)\left(N \sum Y^{2}-\left(\sum Y\right)^{2}\right.}}
$$

Nilai koefisien korelasi yang diperoleh diinterpretasikan menggunakan tabel nilai $r$ product moment. Jika harga rhitung $>$ rtabel maka butir soal tersebut dinyatakan valid.

\section{b. Reliabilitas}

Reabilitas instrumen diuji menggunakan rumus alpha cronbach yaitu sebagai berikut:

$$
\mathrm{r}_{11}=\left(\frac{\mathrm{n}}{\mathrm{n}-1}\right)\left(1-\frac{\sum \sigma_{\mathrm{i}}^{2}}{\sigma_{\mathrm{i}}^{2}}\right)
$$

c. Taraf Kesukaran

Taraf kesukaran butir soal dihitung dengan menggunakan rumus:

taraf kesukaran $=\frac{\text { rata-rata }}{\text { Besar taraf }} \begin{gathered}\begin{array}{c}\text { skor maksimum total } \\ \text { kesukaran kemudian }\end{array} \\ \text { keman }\end{gathered}$ diinterpretasikan sesuai dengan tabel di bawah ini:

Tabel 1. Interpretasi taraf kesukaran butir soal

\begin{tabular}{ll}
\hline \multicolumn{1}{c}{ Nilai $f$} & \multicolumn{1}{c}{ Kriteria } \\
\hline $0,00-0,3$ & Sukar \\
$0,31-0,70$ & Sedang \\
$0,71-1,00$ & mudah \\
\hline
\end{tabular}

\section{d. Daya Beda}

Daya beda butir soal dihitung dengan menggunakan rumus:

$$
\mathrm{D}=\frac{\overline{\mathrm{X}}_{\mathrm{A}}-\overline{\mathrm{X}}_{\mathrm{B}}}{\mathrm{X}_{\max }}
$$

Kemudian hasil yang didapat diinterpretasikan dalam tabel di bawah ini.

\begin{tabular}{|c|c|}
\hline Nilai D & Kategori \\
\hline Negatif & dibuang \\
\hline $0-0,20$ & Jelek (poor) \\
\hline $0,20-0,40$ & $\begin{array}{l}\text { Cukup } \\
\text { (satisfactory) }\end{array}$ \\
\hline $0,40-0,70$ & Baik (good) \\
\hline $0,70-1$ & $\begin{array}{ll}\text { Baik } & \text { sekali } \\
\text { (excellent) }\end{array}$ \\
\hline
\end{tabular}

Tabel 2. Tabel interpretasi daya pembeda soal

\section{Uji Kelayakan}

a. Analisis Data Penilaian Panelis

Data angket mengenai tanggapan panelis terkait kelayakan LKS praktikum berbasis pendekatan saintifik dianalisis. Kemudian skor yang diperoleh dari seluruh aspek yang dinilai, dihitung dengan rumus:

$$
\mathrm{NP}=\frac{\mathrm{R}}{\mathrm{SM}} \times 100 \%
$$

Langkah selanjutnya adalah menghitung rata-rata nilai validitas dari ketiga validator dengan rumus:

$$
\mathrm{NA}=\frac{\mathrm{V} 1+\mathrm{V} 2+\mathrm{V} 3}{3}
$$

Nilai tersebut kemudian dikonversikan dengan kriteria penilaian sebagai berikut:

Tabel 3. Kriteria analisis penilaian panelis

\begin{tabular}{ll}
\hline \multicolumn{1}{c}{ Interval } & \multicolumn{1}{c}{ Kriteria } \\
\hline $81 \%-100 \%$ & Sangat layak \\
$62 \%-81 \%$ & Layak \\
$43 \%-62 \%$ & Cukup layak \\
$33 \%-43 \%$ & Kurang layak \\
$0-33 \%$ & Tidak layak \\
\hline
\end{tabular}

Indikator kelayakan LKS praktikum berbasis pendekatan saintifik apabila ratarata nilai validitas akhir dari ketiga validator $>62 \%$ dengan kriteria layak atau sangat layak.

\section{b. Analisis Angket Respon Siswa}

LKS yang dikembangkan dikatakan praktis jika rata-rata respon siswa lebih dari $60 \%$ atau interpretasi kepraktisan menunjukkan tinggi atau sangat tinggi. Langkah awal dalam tahap ini adalah menghitung jumlah responden melalui pilihan 
jawaban pada setiap butir pernyataan. Setelah itu nilai skor angket per item dicari dengan mengalikan jumlah responden dan skor pilihan jawaban sesuai kriteria pernyataan positif dan negatif. Berikut adalah skor tiap jawaban untuk menghitung nilai skor angket per item [1].

Tabel 4. Skor pilihan jawaban angket respon

\begin{tabular}{lcc}
\multicolumn{3}{c}{ siswa } \\
\hline Pilihan jawaban & $\begin{array}{c}\text { Pernyataan } \\
\text { positif }\end{array}$ & $\begin{array}{c}\text { Pernyataan } \\
\text { negatif }\end{array}$ \\
\hline $\begin{array}{l}\text { Sangat setuju (SS) } \\
\text { Setuju (S) }\end{array}$ & 4 & 1 \\
Kurang setuju & 3 & 2 \\
(KS) & 2 & 3 \\
Tidak setuju (TS) & 1 & 4 \\
\hline
\end{tabular}

Setelah jumlah keseluruhan dari nilai skor angket per item ditentukan, kemudian dicari nilai dengan rumus :

$$
\text { Nilai }=\frac{\sum \text { nilai }}{\text { skor maksimum }} \times 100 \%
$$

Untuk menentukan skor maksimum maka jumlah responden dikalikan dengan skor pilihan terbaik dari pernyataan positif dan negatif yaitu 4 . Setelah itu dihitung banyaknya kriteria sangat rendah, rendah, tinggi, dan sangat tinggi dari seluruh butir pernyataan dengan menggunakan kriteria seperti pada tabel berikut ini:

Tabel 5. kriteria nilai respon siswa

\begin{tabular}{ll}
\hline \multicolumn{1}{c}{ Nilai $(\%)$} & \multicolumn{1}{c}{ Kategori } \\
\hline $0 \leq$ nilai $<20$ & Sangat rendah \\
$20 \leq$ nilai $<40$ & Rendah \\
$40 \leq$ nilai $<60$ & Cukup \\
$60 \leq$ nilai $<80$ & Tinggi \\
$80 \leq$ nilai $\leq 100$ & Sangat tinggi \\
\hline
\end{tabular}

\section{c. Aspek Kognitif (Hasil Belajar Siswa)}

LKS yang dikembangkan dikatakan efektif jika sesudah mengikuti pembelajaran dengan menggunakan LKS praktikum berbasis pendekatan saintifik, para peserta didik tuntas lebih besar atau sama dengan $60 \%$ dari jumlah siswa yang ada di kelas tersebut. Siswa dikatakan tuntas jika mendapatkan nilai lebih besar atau sama dengan KKM yang diterapkan oleh sekolah. Persentase ketuntasan hasil belajar siswa di tentukan dengan rumus :

$$
\mathrm{K}=\frac{\text { banyaknya siswa yang tuntas }}{\text { banyaknya siswa dalam kelas }} \times 100 \%
$$

Kemudian diinterpretasikan ke dalam tabel berikut ini:

Tabel 6. Keefektifan hasil belajar siswa

\begin{tabular}{ll}
\hline \multicolumn{1}{c}{ Interval } & \multicolumn{1}{c}{ Kriteria } \\
\hline $\mathrm{K}>80 \%$ & Sangat efektif \\
$60 \%<\mathrm{K} \leq 80 \%$ & Efektif \\
$40 \%<\mathrm{K} \leq 60 \%$ & Cukup \\
$20 \%<\mathrm{K} \leq 40 \%$ & Kurang efektif \\
$\mathrm{K} \leq 20 \%$ & Tidak efektif \\
\hline
\end{tabular}

3. Ujit

Untuk mengetahui apakah nilai rata-rata hasil belajar peserta didik yang diajar dengan menggunakan LKS praktikum berbasis pendekatan saintifik lebih tinggi dari nilai kriteria ketuntasan minimal (KKM) digunakan uji t pihak kiri menggunakan taraf signifikansi 0,05 dengan rumus sebagai berikut:

$$
t=\frac{\bar{X}-\mu_{0}}{\frac{s}{\sqrt{n}}}
$$

Selanjutnya, nilai thitung yang diperoleh di konsultasikan dengan tabel. Jika thitung $\geq$ tabel, maka $\mathrm{H}_{0}$ diterima dan $\mathrm{H}_{1}$ ditolak.

\section{Hasil dan Pembahasan}

Penelitian ini difokuskan pada uji kelayakan Lembar Kerja Siswa (LKS) praktikum berbasis pendekatan saintifik dan dampaknya terhadap hasil belajar. Oleh karena itu peneliti terlebih dahulu mengembangkan LKS praktikum yang akan diuji cobakan dengan tujuan untuk menghasilkan produk yang bisa dijadikan sebagai salah satu pilihan penggunaan bahan ajar praktikum dalam pembelajaran kimia terlebih khusus pada sub materi sifat larutan penyangga di SMA Negeri 1 Tondano. Langkah-langkah yang digunakan dalam penelitian ini dilakukan dengan menggunakan metode pengembangan dari Borg \& Gall yang meliputi:

\section{Penelitian dan Pengumpulan Data awal}

Langkah awal dalam penelitian ini adalah analisis kebutuhan, mengkaji literatur, serta mengidentifikasi masalah. Dalam tahapan analisis kebutuhan peneliti menganalisis kurikulum yang terdapat dalam silabus kimia 
kurikulum 2013, kemudian mengadakan wawancara dengan guru kimia sehingga didapatkan permasalahan-permasalahan yang dialami siswa sehingga perlu untuk mengembangkan suatu produk baru.

\section{Perencanaan}

Setelah melakukan studi pendahuluan, peneliti bermaksud untuk membuat produk berupa LKS praktikum berbasis pendekatan saintifik pada materi larutan penyangga dengan tujuan untuk menguji kelayakan produk meliputi uji validasi panelis, kepraktisan produk (respon siswa) dan dampak produk yang dikembangkan terhadap hasil belajar. LKS praktikum yang dikembangkan berisi sintaks pendekatan saintifik yaitu: mengamati, menanya, mengumpulkan data, mengasosiasikan dan mengkomunikasikan. Selain sintaks pendekatan saintifik, didalam LKS juga berisi ringkasan materi yang mudah dipahami, serta gambar-gambar yang mendukung materi sifat larutan penyangga.

\section{Pengembangan Draft Produk}

Dalam tahap ini rancangan awal LKS mulai disusun beserta dengan instrumen lain yang dibutuhkan dalam penelitian. Kemudian instrumen tersebut divalidasi terlebih dahulu oleh para panelis. Proses ini dilakukan untuk melihat kekurangan atau kelemahan instrumen yang disusun sebelumnya sehingga dapat digunakan sebagai acuan dalam proses revisi. Berikut ini hasil rekapitulasi instrumen penelitian:

\section{Analisis Soal Posttest}

Dari hasil uji validitas diperoleh bahwa dari 10 butir soal essay terdapat 5 butir soal yang valid Sedangkan untuk uji reliabilitas didapat bahwa pada $\alpha=5 \%$ dengan $\mathrm{N}=25$ diperoleh rtabel $=0,413$ karena $r_{n}=0,612>$ rtabel, maka soalsoal tersebut reliabel.

Rekapitulasi validasi RPP

Tabel 7. Rekapitulasi validasi RPP

\begin{tabular}{clc}
\hline No & \multicolumn{1}{c}{ Aspek penilaian } & skor \\
\hline 1. & $\begin{array}{l}\text { Identitas yang termuat sudah } \\
\text { lengkap }\end{array}$ & 4 \\
& $\begin{array}{l}\text { Rumusan tujuan pembelajaran } \\
\text { sesuai dengan standar } \\
\text { kompetensi dan kompetensi }\end{array}$ & 4 \\
\hline
\end{tabular}

dasar

Rumusan tujuan pembelajaran sesuai dengan rumus $\mathrm{ABCD}$

3. (Audience, behaviour, condition, 4 degree)

Rumusan tujuan pembelajaran

4. sesuai dengan materi yang 4 diajarkan

Langkah-langkah dalam tiap

5. tahapan pembelajaran sudah sesuai dengan alokasi waktu

Sumber belajar/media sudah

6. sesuai dengan tujuan pembelajaran

Sumber belajar/media sudah

7. sesuai dengan materi pembelajaran

Pendekatan dan metode

8. pembelajaran sudah sesuai dengan tujuan pembelajaran

Pendekatan dan metode

9. pembelajaran sudah sesuai dengan materi pembelajaran

Bahasa yang digunakan sudah

10. sesuai dengan EYD (ejaan yang disempurnakan)

11. Penilaian sudah sesuai dengan tujuan pembelajaran

Instrumen yang digunakan

12. dalam pembelajaran sudah 4 lengkap

Nilai validitas RPP

$100 \%$

Rekapitulasi validasi angket respon siswa

Tabel 8. Rekapitulasi validasi angket respon siswa

\begin{tabular}{llc}
\hline No & \multicolumn{1}{c}{ Aspek penilaian } & skor \\
Pernyataan mengenai & \\
tanggapan siswa pada \\
poin 1 dalam angket \\
respon, sudah relevan \\
Pernyataan mengenai \\
tanggapan siswa pada \\
poin 2 dalam angket \\
respon, sudah relevan \\
$\begin{array}{l}\text { Pernyataan mengenai } \\
\text { tanggapan siswa pada } \\
\text { poin 3 dalam angket } \\
\text { respon, sudah relevan }\end{array}$ \\
\hline
\end{tabular}


Pernyataan mengenai

4. tanggapan siswa pada

poin 4 dalam angket

respon, sudah relevan

Pernyataan mengenai

5. tanggapan siswa pada

poin 5 dalam angket

respon sudah relevan

Pernyataan mengenai

6. tanggapan siswa pada

poin 6 dalam angket

respon sudah relevan

Nilai validitas angket respon siswa

Dari hasil rekapitulasi perhitungan pada tabel 7 dan 8 diperoleh nilai validitas berturutturut $100 \%$ dan $91,6 \%$ yang termasuk pada kriteria sangat tinggi. Hal ini berarti instrumen penelitian tersebut layak untuk digunakan.

Tahap selanjutnya adalah melakukan validasi LKS yang dilakukan masing-masing oleh 1 orang panelis materi, panelis media dan panelis bahasa yang ditunjukan pada tabel di bawah ini:

\section{Rekapitulasi validasi panelis materi}

Tabel 9. Rekapitulasi validasi panelis materi

\begin{tabular}{|c|c|c|}
\hline No & Aspek penilaian & skor \\
\hline 1. & Kesesuaian judul & 4 \\
\hline 2. & $\begin{array}{l}\text { Kesesuaian materi dengan } \\
\text { tujuan pembelajaran dan } \\
\text { kompetensi dasar }\end{array}$ & 4 \\
\hline 3. & $\begin{array}{l}\text { Kebenaran konsep materi } \\
\text { ditinjau dari aspek keilmuan }\end{array}$ & 4 \\
\hline 4. & $\begin{array}{l}\text { Kesesuaian dengan tingkat } \\
\text { kematangan berpikir siswa }\end{array}$ & 4 \\
\hline 5. & $\begin{array}{l}\text { Kesesuaian dengan tahapan } \\
\text { pendekatan saintifik }\end{array}$ & 4 \\
\hline 6. & $\begin{array}{l}\text { Kejelasan langkah kerja LKS } \\
\text { praktikum }\end{array}$ & 4 \\
\hline 7. & $\begin{array}{l}\text { Kelengkapan komponen LKS } \\
\text { Praktikum }\end{array}$ & 4 \\
\hline & persentase kevalidan materi & $100 \%$ \\
\hline
\end{tabular}

\section{Rekapitulasi validasi panelis media}

Tabel 10. Rekapitulasi validasi panelis media

\begin{tabular}{clc}
\hline No & \multicolumn{1}{c}{ Aspek penilaian } & skor \\
\hline 1. & Keteraturan desain & 2 \\
2. & Cetak huruf dan gambar & 3 \\
3. & Jenis huruf dan angka & 3 \\
4. & Ukuran huruf dan angka & 3 \\
5. & Gradasi warna & 3 \\
6. & Kemudahan penggunaan & 3 \\
7. & Kemenarikan penampilan & 3 \\
& Persentase kevalidan media & $71,5 \%$ \\
\hline
\end{tabular}

Rekapitulasi validasi panelis bahasa

Tabel 11. Rekapitulasi validasi panelis bahasa

\begin{tabular}{|c|c|c|}
\hline No & Aspek penilaian & skor \\
\hline 1. & Kebakuan bahasa & 3 \\
\hline 2. & $\begin{array}{l}\text { Kesesuaian bahasa dengan ejaan } \\
\text { yang disempurnakan (EYD) }\end{array}$ & 3 \\
\hline 3. & Kesantunan bahasa & 4 \\
\hline 4. & $\begin{array}{l}\text { Dukungan bahasa terhadap } \\
\text { kemudahan memahami alur } \\
\text { praktikum }\end{array}$ & 3 \\
\hline 5. & $\begin{array}{l}\text { Tidak adanya kalimat yang } \\
\text { menimbulkan makna ganda }\end{array}$ & 3 \\
\hline & Persentase kevalidan bahasa & $80 \%$ \\
\hline
\end{tabular}

Rekapitulasi perhitungan validasi LKS praktikum berbasis pendekatan saintifik pada tabel 9, 10, dan 11 menunjukkan nilai kevalidan sebesar $100 \%$, 71,5\% dan 80\%. Kemudian dari hasil persentase ketiga panelis yang diperoleh dihitung nilai rata-rata validitas yaitu sebesar $83,8 \%$ dengan kriteria sangat layak. Sehingga dapat disimpulkan bahwa LKS praktikum berbasis pendekatan saintifik layak diuji cobakan pada peserta didik.

\section{Uji Coba kelompok kecil}

Uji coba kelompok kecil dalam penelitian ini melibatkan 6 orang siswa kelas XI IPA 5 SMAN 1 Tondano sebagai sampel. siswa dikondisikan untuk membentuk 2 kelompok dengan jumlah siswa masing-masing kelompok sebanyak 3 orang, kemudian setiap kelompok diberikan LKS praktikum berbasis pendekatan saintifik.

Kegiatan belajar mengajar pada uji coba ini terdiri dari tiga tahap kegiatan, yaitu tahap 
kegiatan pendahuluan, kegiatan inti, dan kegiatan penutup. Kegiatan pendahuluan diisi dengan penyampaian tujuan dan rencana kegiatan praktikum dalam pembelajaran serta apersepsi yang diberikan oleh guru sehingga siswa termotivasi untuk mempelajari sifat larutan penyangga. Tahap kegiatan inti, siswa menyimak penjelasan tentang sifat larutan penyangga sambil memperhatikan LKS praktikum berbasis pendekatan saintifik. Selanjutnya siswa diarahkan pada tahap-tahap pendekatan saintifik yang tersedia dalam lembar LKS. Kegiatan akhir pembelajaran yaitu kegiatan penutup, siswa dan peneliti secara bersama-sama menyimpulkan secara keseluruhan pembelajaran yang telah dilaksanakan.

Untuk menentukan kepraktisan LKS praktikum berbasis pendekatan saintifik pada uji coba kelompok kecil, maka siswa diminta mengisi angket respon. Sedangkan untuk mengetahui dampak penggunaan LKS dalam pembelajaran kimia pada submateri sifat larutan penyangga, maka siswa diminta untuk mengerjakan soal posttest yang telah diberikan oleh peneliti.

\section{Revisi Produk Hasil Uji Coba Kelompok Kecil}

Pada tahap ini dilakukan revisi berdasarkan analisis komentar/saran yang diberikan oleh siswa terhadap LKS.

\section{Uji coba kelompok besar}

Uji coba kelompok besar melibatkan siswa yang tersisa setelah uji coba kelompok kecil, yaitu 19 siswa sebagai sampel. Siswa dibagi menjadi 4 kelompok dengan jumlah siswa untuk 3 kelompok sebanyak 5 orang dan 1 kelompok beranggotakan 4 orang. Kemudian setiap kelompok diberikan LKS praktikum berbasis pendekatan saintifik.

Sama seperti pada uji coba kelompok kecil, uji coba kelompok besar juga terdiri dari tiga tahap kegiatan. Pada tahap Kegiatan pendahuluan diisi dengan penyampaian tujuan dan rencana kegiatan praktikum dalam pembelajaran serta apersepsi yang diberikan oleh guru sehingga siswa termotivasi untuk mempelajari sifat larutan penyangga. Tahap kegiatan inti, siswa menyimak penjelasan tentang sifat larutan penyangga sambil memperhatikan LKS praktikum berbasis pendekatan saintifik. Selanjutnya siswa diarahkan pada tahap-tahap pendekatan saintifik yang tersedia dalam lembar LKS. Kegiatan akhir pembelajaran yaitu kegiatan penutup, siswa dan peneliti secara bersamasama menyimpulkan secara keseluruhan pembelajaran yang telah dilaksanakan.

Untuk menentukan kepraktisan LKS praktikum, maka siswa diminta mengisi angket respon. Sedangkan untuk mengetahui dampaknya dalam pembelajaran kimia pada submateri sifat larutan penyangga, maka siswa diminta untuk mengerjakan soal posttest yang telah diberikan.

Adapun rekapitulasi hasil analisis angket respon siswa dapat dilihat pada tabel 12 .

Tabel 12. Rekapitulasi hasil angket respon siswa

\begin{tabular}{lc}
\hline \multicolumn{1}{c}{ Tahapan } & $\begin{array}{c}\text { Nilai respon } \\
\text { siswa }\end{array}$ \\
\hline Uji coba kelompok kecil & $88,17 \%$ \\
Uji coba kelompok besar & $92,98 \%$ \\
\hline
\end{tabular}

Sesuai dengan kategori yang ditetapkan, nilai respon siswa pada kedua uji coba tersebut berada pada interval $80 \%-100 \%$ yang menunjukan kriteria sangat tinggi. hal ini berarti LKS praktikum berbasis pendekatan saintifik sangat praktis untuk digunakan.

Tabel 13. Rekapitulasi hasil post-test siswa uji coba kelompok kecil dan uji coba kelompok besar

\begin{tabular}{lcc}
\hline & $\begin{array}{c}\text { Uji coba } \\
\text { kelompok } \\
\text { kecil }\end{array}$ & $\begin{array}{c}\text { Uji coba } \\
\text { kelompok } \\
\text { besar }\end{array}$ \\
\hline $\begin{array}{l}\text { Jumlah siswa } \\
\text { Jumlah siswa } \\
\text { tuntas }\end{array}$ & 6 & 19 \\
$\begin{array}{l}\text { Jumlah siswa } \\
\text { tidak tuntas } \\
\begin{array}{l}\text { Persentase } \\
\text { ketuntasan }\end{array}\end{array}$ & 2 & 17 \\
\hline
\end{tabular}

Tabel 13 menunjukkan persentase hasil posttest pada uji coba kelompok kecil dan uji coba kelompok besar. Berdasarkan nilai yang diperoleh bahwa siswa tuntas lebih dari $60 \%$ dari jumlah siswa yang ada di kelas. Dari data tersebut dapat disimpulkan bahwa LKS praktikum berbasis pendekatan saintifik, telah 
memenuhi aspek keefektifan.

\section{Uji Hipotesis Untuk Hasil Belajar Siswa}

Dari hasil pengujian diperoleh nilai thitung $=$ 8,517. Pada taraf signifikan $\alpha=0,05, \mathrm{df}=18$, didapatkan tabel $=1,734$. Karena thitung $=8,517$ berada pada daerah penerimaan $\mathrm{H}_{0}$, berarti thitung lebih besar dari tabel, di mana sesuai kriteria pengujian jika thitung $\geq$ tabel maka $\mathrm{H}_{0}$ diterima dan $\mathrm{H}_{1}$ ditolak. Hal tersebut berarti bahwa rata-rata hasil belajar peserta didik setelah menggunakan LKS praktikum berbasis pendekatan saintifik lebih tinggi dari nilai KKM (75).

\section{Kesimpulan}

Berdasarkan data yang telah diperoleh maka disimpulkan bahwa LKS praktikum berbasis pendekatan saintifik dikatakan layak untuk digunakan dengan nilai kevalidan produk sebesar. $83 \%$ serta nilai respon siswa untuk uji coba kelompok kecil dan kelompok besar berturut-turut adalah sebesar $88,17 \%$ dan $92,98 \%$ dengan kriteria sangat tinggi. Untuk dampak penggunaan LKS praktikum berbasis pendekatan saintifik didapatkan bahwa banyak peserta didik yang tuntas melebihi nilai KKM yang ditetapkan, di mana hasil persentase ketuntasan siswa pada uji coba kelompok kecil dan kelompok besar berturut-turut adalah sebesar $66,67 \%$ dan $89,47 \%$.

\section{Daftar Pustaka}

1. Utari, W. T. Dkk. Pengembangan Lembar Kerja Siswa (LKS) Praktikum Berbasis Inkuiri Terbimbing Pada Materi Larutan Penyangga Di SMA Negeri 4 Sungai Raya. AJI. 2018. 6(1), 69-78.

2. Marsita,A.R., Priatmoko, S., dan Kusuma, E. Analisis Kesulitan Belajar Kimia Siswa SMA Dalam Memahami Materi Larutan Penyangga Dengan Menggunakan TwoTier Multiple Choice Diagnostic Instrument. JIPK. 2010, 4(1), 512-520.

3. Rusiani \& Lazulva. Pengembangan Penuntun Praktikum Titrasi Asam Basa Menggunakan Indikator Alami Berbasis Pendekatan Saintifik. JTK. 2017, 2(2), 159168.

4. Abdurohim, dkk. Pengembangan Lembar Kegiatan Siswa (Lks) Berbasis Inkuiri
Terbimbing Pada Materi Hidrolisis Garam. JPPI. 2016, 2(2), 197-212.

5. Asnaini. Pengembangan LKPD Berbasis Pendekatan Scientific Untuk Meningkatkan Hasil Belajar dan Aktivitas Peserta Didik Pada Materi Larutan Penyangga. LJ. 2016, 4(1), 60-71. 